www.nature.com/tp

\title{
Moderation of antipsychotic-induced weight gain by energy balance gene variants in the RUPP autism network risperidone studies
}

\author{
EL Nurmi ${ }^{1}$, SL Spilman ${ }^{1}$, F Whelan ${ }^{1}$, LL Scahill', MG Aman ${ }^{3}$, CJ McDougle ${ }^{4}$, LE Arnold ${ }^{5}$, B Handen ${ }^{6}$, C Johnson ${ }^{6}$, DG Sukhodolsky ${ }^{2}$, \\ DJ Posey ${ }^{7}$, L Lecavalier ${ }^{3}$, KA Stigler ${ }^{7}$, L Ritz ${ }^{8}$, E Tierney ${ }^{9}$, B Vitiello ${ }^{10}$, JT McCracken ${ }^{1}$ and the Research Units on Pediatric \\ Psychopharmacology Autism Network
}

Second-generation antipsychotic exposure, in both children and adults, carries significant risk for excessive weight gain that varies widely across individuals. We queried common variation in key energy balance genes (FTO, MC4R, LEP, CNR1, FAAH) for their association with weight gain during the initial 8 weeks in the two NIMH Research Units on Pediatric Psychopharmacology Autism Network trials $(N=225)$ of risperidone for treatment of irritability in children/adolescents aged 4-17 years with autism spectrum disorders. Variants in the cannabinoid receptor (CNR)-1 promoter $\left(P=1.0 \times 10^{-6}\right)$, CNR1 $\left(P=9.6 \times 10^{-5}\right)$ and the leptin (LEP) promoter $\left(P=1.4 \times 10^{-4}\right)$ conferred robust-independent risks for weight gain. A model combining these three variants was highly significant $\left(P=1.3 \times 10^{-9}\right)$ with a 0.85 effect size between lowest and highest risk groups. All results survived correction for multiple testing and were not dependent on dose, plasma level or ethnicity. We found no evidence for association with a reported functional variant in the endocannabinoid metabolic enzyme, fatty acid amide hydrolase, whereas body mass index-associated single-nucleotide polymorphisms in FTO and MC4R showed only trend associations. These data suggest a substantial genetic contribution of common variants in energy balance regulatory genes to individual antipsychoticassociated weight gain in children and adolescents, which supersedes findings from prior adult studies. The effects are robust enough to be detected after only 8 weeks and are more prominent in this largely treatment naive population. This study highlights compelling directions for further exploration of the pharmacogenetic basis of this concerning multifactorial adverse event.

Translational Psychiatry (2013) 3, e274; doi:10.1038/tp.2013.26; published online 25 June 2013

\section{Introduction}

Antipsychotic-induced weight gain (AIWG) is a common and limiting side effect of antipsychotic treatment, especially of the widely prescribed second-generation antipsychotics (SGA). ${ }^{1}$ Intersubject variability in this adverse effect may be explained in part by individual genetic differences; heritability may be as high as $80 \%$ based on comparisons of clozapinetreated monozygotic twins and sex-matched siblings. ${ }^{2}$ Although AIWG is thought to be multifactorial, most of the extant research has focused on monoaminergic systems given their role in direct drug effects and their involvement in appetite, satiety, metabolism and activity. ${ }^{3-5}$ Relatively modest variance in AIWG has been explained by association of common variants in these systems, suggesting that additional moderators in other pathways are likely, rare variants may be involved, or that confounding environmental effects exist. Further support for the existence of novel candidates is provided by pharmacogenomic analyses of the CATIE study of SGA-treated adults with schizophrenia, in which weight gain and metabolic effects were variably associated with several genes not considered to be 'drug targets'. 6

Energy balance pathways. Energy intake and expenditure are regulated by the central nervous system, liver, gastrointestinal tract and adipose tissue to maintain energy balance. In the central nervous system, melanocortin 4 receptor (MC4R) signaling has a key role in regulating feeding behavior in the hypothalamus. The central melanocortin system regulates hepatic and adipocyte lipid metabolism. ${ }^{7,8}$ Mutations in the MC4R gene are the most common monogenic cause of severe obesity in humans. ${ }^{9}$ In addition, the mesolimbic dopamine pathway modulates reinforcing and motivational effects of food. The FTO (fat mass and obesity-associated) gene, highly expressed in the hypothalamus, ${ }^{10}$ was identified by a genome-wide association study for its strong association with body mass index $(\mathrm{BMI})^{11}$ and this link was subsequently replicated independently and in a meta-analysis. ${ }^{12}$ FTO expression appears to be sensitive to fasting and feeding. ${ }^{13,14}$

\footnotetext{
${ }^{1}$ Department of Psychiatry and Biobehavioral Sciences, UCLA Semel Institute, Los Angeles, CA, USA; ${ }^{2}$ Child Study Center, Yale University, New Haven, CT, USA; ${ }^{3}$ Department of Psychology, Ohio State University, Columbus, OH, USA; ${ }^{4}$ Lurie Autism Center, Department of Psychiatry, Massachusetts General Hospital, Boston, MA, USA; ${ }^{5}$ Department of Psychiatry, Ohio State University, Columbus, OH, USA; ${ }^{6}$ Department of Psychiatry, University of Pittsburgh, Pittsburgh, PA, USA; ${ }^{7}$ Department of Psychiatry, Indiana University, Indianapolis, IN, USA; ${ }^{8}$ National Institute of Neurological Disorders and Stroke, National Institutes of Health, Bethesda, MD, USA; ${ }^{9}$ Department of Psychiatry, Kennedy Krieger Institute, Baltimore, MD, USA and ${ }^{10}$ National Institute of Mental Health, National Institutes of Health, Bethesda, MD, USA Correspondence: Dr JT McCracken, Department of Psychiatry and Biobehavioral Sciences, UCLA Semel Institute 760 Westwood Plaza, Los Angeles, CA 90024, USA. E-mail: jmccracken@mednet.ucla.edu
}

Keywords: autistic disorder; children; CNR1; leptin; risperidone; weight gain

Received 2 July 2012; revised 6 February 2013; accepted 18 February 2013 
Leptin (LEP) promotes satiety and leanness through multiple inputs to the energy balance circuit. LEP is secreted by adipose tissue in proportion to fat stores, and activates hypothalamic MC4R signaling to inhibit feeding and increase energy expenditure. ${ }^{15}$ Recently, effects on reinforcement and motivation via mesolimbic dopamine signaling have been demonstrated. ${ }^{16,17}$ Peripherally, LEP regulates lipid and glucose metabolism through the autonomic nervous system. ${ }^{18,19}$ Obesity-producing spontaneous null mutations in $\angle E P$ and the LEP receptor ( $L E P R)$ in mice prompted its discovery. ${ }^{20}$ LEP antagonism in rats increases feeding, promotes weight gain and reduces activity. ${ }^{21}$ Although humans genetically lacking LEP are morbidly obese, ${ }^{22}$ mixed association results and a negative meta-analysis ${ }^{23}$ suggest that $L E P$ does not have a major role in common variability in body weight.

Endocannabinoids trigger feeding behavior and weight gain through stimulation of widely expressed cannabinoid 1 (CB1) receptors (CNR1). ${ }^{24}$ In the brain, the endocannabinoid system regulates both mesolimbic reinforcement ${ }^{25,26}$ and hypothalamic feeding pathways. CB1 signaling promotes feeding through positive effects on orexins ${ }^{27}$ and inhibition of MC4R, ${ }^{28}$ and is in turn stimulated by ghrelin ${ }^{29}$ and inhibited by LEP $^{30}$ and cholecystokinin. ${ }^{31}$ Endocannabinoid signaling in the liver and adipose tissue regulates lipid metabolism, adipogenesis and adiponectin release. ${ }^{32}$ CB1 receptor agonism increases and antagonism reduces food intake and body weight in both humans and animal models. ${ }^{33,34}$ Mice lacking CB1 expression exhibit hypophagia and leanness at baseline, and are resistant to high-fat diet-induced metabolic changes, behaviors and obesity. ${ }^{35}$ Polymorphisms in CNR1 and the gene encoding the catabolic enzyme (fatty acid amide hydrolase $(F A A H))$ have been associated with obesity phenotypes; however, data are mixed. ${ }^{36,37}$ In the RIO-North America trial, 2-year treatment with a CB1 antagonist, rimonabant, in combination with a healthy diet, resulted in modest reductions in weight, waist circumference and cardiometabolic risk factors. ${ }^{38}$ The drug did not reach the US market, however, due to psychiatric side effect concerns.

Energy balance candidate genes in AIWG. A few reports have begun to investigate whether variants in metabolic and appetite gene loci, such as $L E P$, may moderate AIWG. ${ }^{5}$ These studies were prompted by observed increases in plasma LEP levels during SGA treatment. ${ }^{39}$ Common LEP gene variants have reportedly moderated AIWG in some but not all studies, ${ }^{5}$ including one pediatric sample. ${ }^{40}$ Variants mapping adjacent to the $M C 4 R$ gene have recently been demonstrated to predict AIWG in multiple independent samples. ${ }^{41,42}$ Given the role of the endocannabinoid system in energy balance and observed CNR1 upregulation in response to antipsychotic treatment, ${ }^{43}$ two recent pharmacogenomic studies have supported a contribution of endocannabinoid involvement. One report demonstrated moderation of AIWG in schizophrenia by a functional polymorphism in CNR1. ${ }^{44}$ A second study demonstrated an association between AIWG and a nonsynonymous variant in the gene encoding the degradative enzyme, $F A A H^{45}$

The established role of the melanocortin, LEP and endocannabinoid systems in energy balance and the association of gene variants with human obesity strongly suggest these systems as possible moderators of AIWG, perhaps as an alternative pathway to direct drug action at monoaminergic and other targets. Relatively few studies have examined the effects of common gene variants in these systems, and to our knowledge, none have attempted a systematic, combined examination of these loci in relation to AIWG. In addition, most reports have not queried each locus thoroughly, relying instead on rather few frequently studied polymorphisms. Importantly, extant genetic studies of variants in the energy balance system have been mainly limited to adults, despite common use of SGAs in children. Reports suggest that pediatric populations are at equal or greater risk of AIWG. ${ }^{46-49}$ In the NIMH Research Units on Pediatric Psychopharmacology (RUPP) trials, weight gain above that predicted with normal development was evident after just 8 weeks and continued after 6 months of risperidone exposure. ${ }^{50}$ Other longitudinal studies show persistent effects at 1 year. $^{48}$ Studying AIWG in children has several scientific advantages, such as fewer concomitant and potentially confounding medical comorbidities and medications, and lower rates of institutionalization, smoking and substance use/abuse. Further, increased weight in children confers serious health risks, social impairment, challenges to self-esteem and risk for adult obesity. In light of the potential importance of energy balance genes as moderators of AIWG and sparse investigation in pediatric samples, we examined the association of genetic variants in these systems with weight gain in our combined sample from two clinical trials of children and adolescents receiving risperidone treatment for severe irritability associated with autism spectrum disorders (ASDs). ${ }^{51,52}$

\section{Materials and methods}

The research was conducted by the RUPP Autism Network under two protocols approved by individual site Institutional Review Boards and by a National Institute of Mental Health Data Safety Monitoring Board. Written informed consent (and assent from the child, when capable) was obtained from a parent or guardian before enrollment. Youth (ages 4-17 years) meeting DSM-IV criteria for ASD (autism, Asperger's disorder, pervasive developmental disorder not otherwise specified) accompanied by severe irritability (aggression, tantrums, and/or self-injurious behaviors) defined by a score of $\geqslant 18$ on the Aberrant Behavior Checklist Irritability subscale were treated for 8 weeks with risperidone or placebo as part of two controlled trials, RUPP ${ }^{51}$ and RUPP-PI (RUPP-Psychosocial Intervention)..$^{51,52}$ Only $10 \%$ of subjects had previously received (ineffective) antipsychotic treatment; subjects with prior adequate trials of risperidone were excluded. In the RUPP sample, subjects included both those randomized first to risperidone in the 8-week acute phase and non-responders to 8 weeks of initial placebo treatment who were then openly treated with risperidone according to an identical titration and assessment protocol. ${ }^{51}$ In the RUPP-PI study, all subjects received risperidone, titrated as in the RUPP study, with or without parent behavior management for up to 24 weeks. ${ }^{52}$ Of the 225 total outpatients enrolled from the two trials, weekly measures of weight, height, BMI and genotype data were available for a combined 184 subjects from their initial 8-week acute exposure to risperidone. Plasma drug and metabolite 
Table 1 Characteristics of the RUPP, RUPP-PI and combined RUPP risperidone Autism samples

\begin{tabular}{|c|c|c|c|c|}
\hline & $R U P P(\mathrm{n}=71)$ & $R U P P-P I(\mathrm{n}=110)$ & Combined $(\mathrm{n}=181)$ & P-value \\
\hline $\begin{array}{l}\text { Gender ( } n(\%) \text { male) } \\
\text { Baseline age (months) } \\
\text { Baseline BMI }\end{array}$ & $\begin{array}{c}56(78.9 \%) \\
106.66 \pm 34.5 \\
18.2 \pm 4.9\end{array}$ & $\begin{array}{c}92(83.6 \%) \\
89.96 \pm 29.0 \\
17.7 \pm 3.1\end{array}$ & $\begin{array}{l}148(81.8 \%) \\
96.5 \pm 32.3 \\
17.9 \pm 3.92\end{array}$ & $\begin{array}{c}\chi^{2}=0.66, P=0.4177 \\
T=3.51, P=0.0006 \\
T=0.85, P=0.40\end{array}$ \\
\hline $\begin{array}{l}\text { Ethnicity }(n(\%)) \\
\text { White, non-Hispanic } \\
\text { Black, non-Hispanic } \\
\text { Native American } \\
\text { Asian or Pacific Islander } \\
\text { Hispanic } \\
\text { Black, Hispanic } \\
\text { Other }\end{array}$ & $\begin{array}{c}51(71.8 \%) \\
6(8.5 \%) \\
0 \\
7(9.9 \%) \\
2(2.8 \%) \\
0 \\
5(7.0 \%)\end{array}$ & $\begin{array}{c}74(67.3 \%) \\
20(18.2 \%) \\
2(1.8 \%) \\
5(5.5 \%) \\
7(6.4 \%) \\
1(0.9 \%) \\
0\end{array}$ & $\begin{array}{r}125(69.0 \%) \\
26(14.4 \%) \\
2(1.1 \%) \\
13(7.2 \%) \\
9(5.0 \%) \\
1(0.6 \%) \\
5(2.8 \%)\end{array}$ & $\chi^{2}=14.9, P=0.02$ \\
\hline $\begin{array}{l}\text { Duration of treatment } \\
\text { Median (range) weeks } \\
\text { Final dose (mg) } \\
\text { Mean weight gain }(\mathrm{kg})\end{array}$ & $\begin{array}{c}8(6-8) \\
1.84 \pm 0.63 \\
2.84 \pm 2.05\end{array}$ & $\begin{array}{c}8(1-8) \\
2.09 \pm 0.59 \\
2.57 \pm 1.51\end{array}$ & $\begin{array}{c}8(1-8) \\
2.00 \pm 0.62 \\
2.68 \pm 1.74\end{array}$ & $\begin{array}{c}\chi^{2}=4.08, P=0.54 \\
T=-2.66, P=0.0084 \\
T=0.97, P=0.3317\end{array}$ \\
\hline
\end{tabular}

Abbreviations: BMI, body mass index; RUPP, Research Units on Pediatric Psychopharmacology; RUPP-PI, RUPP-psychosocial intervention.

Table 2 Association of genetic variants in energy balance pathways with AIWG

\begin{tabular}{|c|c|c|c|c|c|c|}
\hline Gene & SNP ID (rs\#) & Gene region & Our MAF & НарМар MAF & P-value & Prior association \\
\hline \multirow[t]{6}{*}{ FTO } & rs1421085 & Intron 1 & 0.33 & 0.45 & 0.13 & 12 \\
\hline & rs6499640 & Intron 1 & 0.41 & 0.35 & 0.88 & 81 \\
\hline & rs1121980 & Intron 1 & 0.41 & 0.48 & 0.78 & 12,82 \\
\hline & rs $17817449^{a}$ & Intron 1 & 0.39 & 0.45 & & 83 \\
\hline & rs8050136 & Intron 1 & 0.38 & 0.45 & & 12 \\
\hline & rs9939609 & Intron 1 & 0.38 & 0.45 & & 11,73 \\
\hline \multirow[t]{4}{*}{$M C 4 R$} & rs8087522 & Promoter & 0.36 & 0.36 & 0.06 & 41,84 \\
\hline & rs11872992 & Promoter & 0.12 & 0.13 & 0.03 & 41,84 \\
\hline & rs8093815 & $3^{\prime}$ Downstream & 0.32 & 0.33 & 0.07 & \\
\hline & rs489693 & 3' Downstream & 0.39 & 0.34 & 0.03 & 85 \\
\hline \multirow[t]{4}{*}{$L E P$} & rs7799039 & promoter & 0.43 & 0.49 & $1.4 \times 10^{-4}$ & $72,86,87$ \\
\hline & rs10244329 & Intron 1 & 0.49 & 0.47 & $9.6 \times 10^{-3}$ & 88 \\
\hline & rs12706832 & Intron 1 & 0.49 & 0.57 & 0.09 & \\
\hline & rs2071045 & Intron 2 & 0.24 & 0.21 & 0.19 & 89 \\
\hline \multirow[t]{4}{*}{ CNR1 } & rs806378 & Variable ${ }^{b}$ & 0.24 & 0.26 & $1.0 \times 10^{-6}$ & 44 \\
\hline & rs806377 & Promoter & 0.46 & 0.49 & 0.17 & \\
\hline & rs1049353 & Synonymous & 0.23 & 0.23 & $9.6 \times 10^{-5}$ & \\
\hline & rs806368 & $3^{\prime}$ UTR & 0.18 & 0.25 & 0.26 & \\
\hline$F A A H$ & rs324420 & Nonsynonymous & 0.25 & 0.21 & 0.19 & 45 \\
\hline
\end{tabular}

Abbreviations: AIWG, antipsychotic-induced weight gain; CNR, cannabinoid receptor; MAF, minor allele frequency; SNP, single-nucleotide polymorphism; UTR, untranslated region.

${ }^{a}$ FTO SNPs removed from analysis due to near perfect linkage disequilibrium with rs 1121980 . ${ }^{\mathrm{b}} \mathrm{rS} 806378$ maps to either a promoter, $5^{\prime} \mathrm{UTR}$, or intronic location in alternatively processed $C N R 1$ transcripts.

Bolded $P$-values are significant after Bonferroni-correction for 19 tests.

levels were analyzed for the RUPP sample according to previously published protocols. ${ }^{53}$

The RUPP and RUPP-PI groups were compared using the appropriate $\chi^{2}$, analysis of variance or $t$-test to ensure comparable samples (Table 1). Baseline variables that were significantly different between the two groups were tested in the final model and dropped if they showed no significant effect on outcome. Weight was transformed to standardized $z$ scores using anthropometric indices based on the 2000 CDC growth charts using the CDC SAS program, ${ }^{54}$ as described in a previous report. ${ }^{50} \mathrm{~A}$ separate repeated measures mixed effects model was constructed for each single-nucleotide polymorphism (SNP) with change in weight z-score from baseline as the main outcome. Genotype, visit (as a continuous variable) and interaction of genotype by visit were entered as predictors, controlling for baseline weight $z$-score.
Other potentially confounding covariates were entered in the initial model such as dose, plasma drug level and ethnicity, but were nonsignificant and therefore dropped from the final model.

The linkage disequilibrium (LD) structure of MC4R, LEP and CNR1 were examined using the Broad Institute Tagger software ${ }^{55}$ to select markers (Table 2), which span each gene and capture common variability $(>1 \%)$ in this genomic region, with a mean $\max r^{2}>0.98$ for $L E P$ and $r^{2}=1$ for $M C 4 R$. Our $C N R 1$ tag is less robust according to the latest genome build, with a mean max $r^{2}>0.61$ for alleles with $>10 \%$ frequency across the CNR1-coding region. Tags were chosen based on the European Caucasian reference genome, given that our population is $70 \%$ Caucasian and thus provides little power to detect population-specific alleles in non-Caucasian subsets. A well-characterized, functional variant (rs324420) in $F A A H$ 
was included to more comprehensively evaluate the endocannabinoid system. Six SNPs in FTO with genome-wide association study support for obesity were also examined; however, four of these were in near perfect LD, thus only one was included in the final analyses. Genomic DNA was extracted from whole blood using QiaAmp DNA Blood Mini Kits (Qiagen, Valencia, CA, USA). Genotyping was performed using the TaqMan genotyping platform (Life Technologies, Grand Island, NY, USA) with Qiagen Type-it Fast SNP Probe PCR Kit (Qiagen) according to manufacturer's protocols. All markers were in Hardy-Weinberg equilibrium, $10 \%$ of the data set was genotyped in duplicate with perfect concordance, and allele frequencies were consistent with those reported by the HapMap Consortium (Table 2). ${ }^{56}$ Functional potential of associated SNPs was explored using online databases, including the online UCSC Genome Browser ${ }^{57}$ with ENCODE tracks ${ }^{58}$ and the Broad Institute's HaploReg online resource (accessed 4 November 2012). ${ }^{59}$

A combined risk variable was constructed using the three significant markers, in part to examine the relative independence of each marker. Genotype at each locus was given a score of 0 or 1 , with 1 denoting the presence of at least one risk allele. Scores were summed across the three loci and each subject received an overall risk score ranging from 0 to 3 . A similar repeated measures mixed effects model (predicting change in weight $z$-score based on risk score, visit and visit by risk score) was applied, with baseline weight as a covariate.

\section{Results}

The two studies were roughly equivalent with respect to demographic and baseline characteristics, final risperidone daily dose and weight gained (Table 1). Statistical comparisons of the two study populations showed small clinical differences: RUPP-1 subjects were 16.7 months older, weighed $0.27 \mathrm{~kg}$ more at baseline and received an average of $0.25 \mathrm{mg}$ less total daily risperidone compared with RUPP-PI participants. Whereas both samples were predominantly Caucasian $(\sim 70 \%)$, there were minor ethnicity differences across the samples. As a result, significant associations with gene variants were repeated with ethnicity and risperidone dose as covariates. The mean absolute weight increase for the combined sample (Table 1) was $2.68 \pm 1.74 \mathrm{~kg}(9.8 \%$ of baseline) with an increase in BMI of $8.3 \%$ from baseline (final $\mathrm{BMI}=19.3 \pm 3.9$ ) following 8 weeks of risperidone exposure (mean final dose $2 \pm 0.62 \mathrm{mg}$ per day). Of note, the decrease in Aberrant Behavior Checklist-Irritability subscale score (primary outcome) from baseline to 8 weeks was significantly inversely correlated with weight gain in kilograms $(r=-0.36$, $P<0.0001)$. Drop-out rates were very low with more than $95 \%$ completing the entire 8-week study.

Three independent gene variants were associated with z-score weight change at a Bonferroni-corrected significance level, one in LEP and two in CNR1 (Figure 1; Supplementary Table 1). The T-allele of the CNR1 rs806378 polymorphism predicted an allele dosage-dependent increase in AIWG $\left(P=1.0 \times 10^{-6}\right.$, Figure 1a). The increase in age-corrected $\mathrm{BMI}$ for the three genotype groups was 1.85 for TT homozygotes, 1.57 for CT heterozygotes and 1.34 for CC homozygotes. The G-allele of the commonly studied (rs1049353) synonymous variant in the large, final exon of CNR1 conferred an independent risk for weight gain $(P=9.6$ $\left.\times 10^{-5}\right)$, suggesting allelic heterogeneity at this locus. G-allele carriers gained more weight than AA homozygotes, with change in BMI of 1.25 for GG homozygotes, versus 1.49 for AG heterozygotes and AA homozygotes. The G-allele of the LEP rs7799039 promoter SNP acted dominantly to increase weight gain compared with A-allele homozygotes $\left(P=1.4 \times 10^{-4}\right.$, Figure $\left.1 \mathrm{~b}\right)$. Change in BMl of GG homozygotes and $A G$ heterozygotes was 1.37 and 1.43 respectively, compared with 1.07 in AA homozygotes. A second marker, rs10244329, produced a weaker association $\left(9.6 \times 10^{-3}\right)$ that was a result of modest LD with this associated variant but conferred no independent effects. None of the FTO obesityassociated markers were related to AIWG in our sample (Table 2). Several MC4R variants showed a trend association, but none met significance after correction for multiple comparisons (adjusted significance threshold for 19 markers $P<0.003)$. The single nonsynonymous variant in $F A A H$ did not achieve significance in our data set.
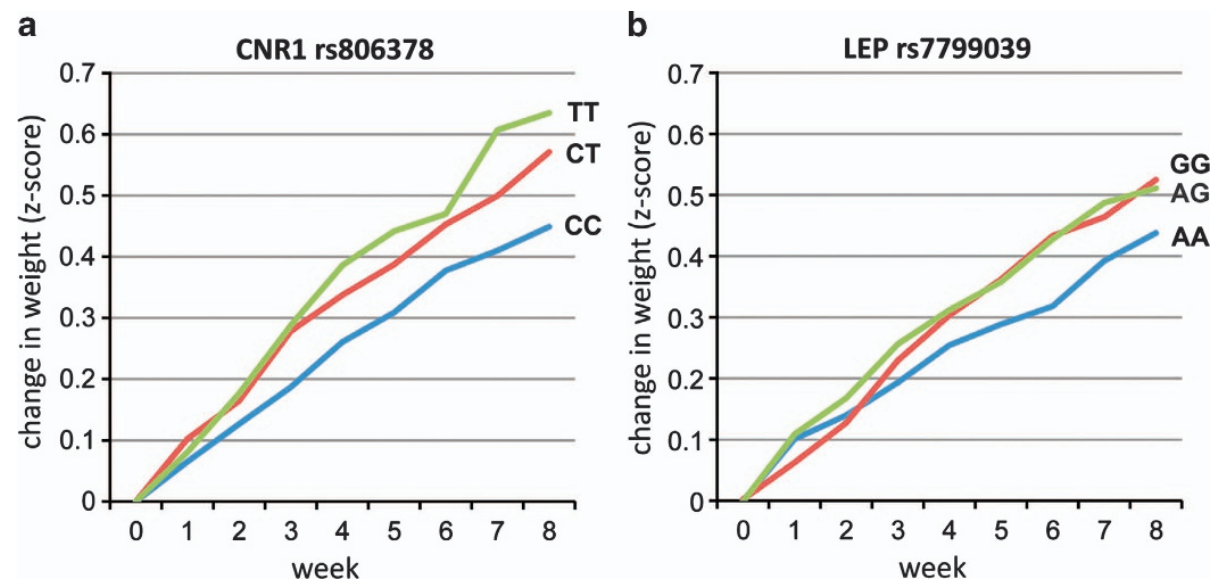

Figure 1 Gene variants predict weight gain across 8 weeks of risperidone treatment. (a) A greater risk for weight gain is conferred by T-allele dosage at cannabinoid receptor (CNR1) rs806378 $\left(P=1.0 \times 10^{-6}\right)$. (b) The G-allele of leptin (LEP) rs7799039 acts dominantly to increase risk for antipsychotic-induced weight gain $\left(P=1.4 \times 10^{-4}\right)$, whereas AA homozygotes are relatively protected. 


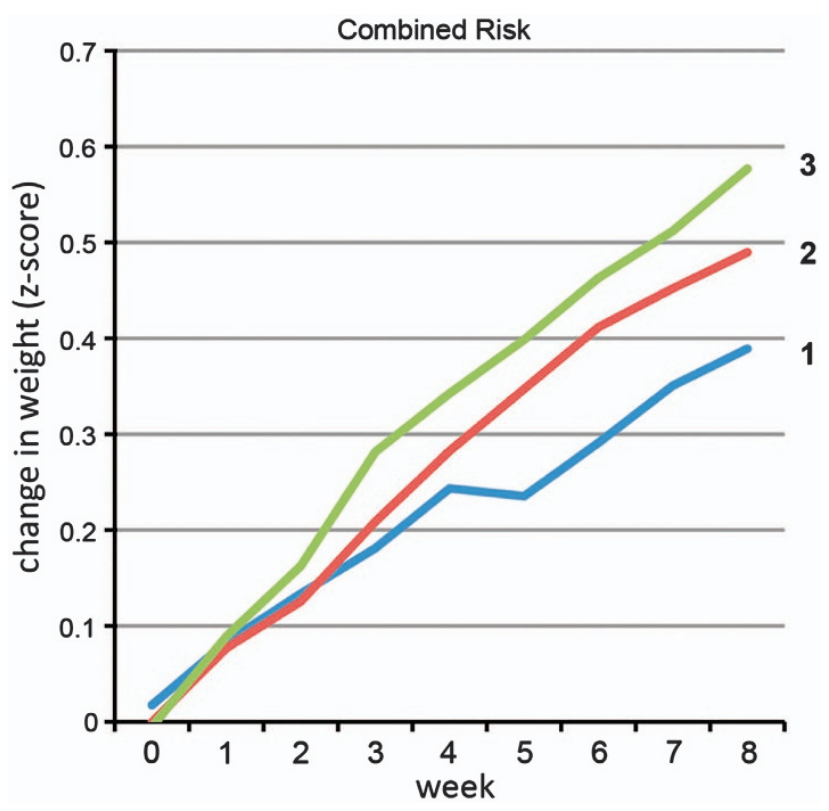

Figure 2 Amount of weight gain is moderated by risk allele load. A risk score $(0-3)$ was assigned to each subject corresponding to the number of loci with risk alleles present for each significant marker (leptin rs7799039 and cannabinoid receptor 1 rs806378 and rs1049353). Risk allele dosage predicted amount of weight gain $\left(P=1.29 \times 10^{-9}\right.$, Cohen's $D$ effect size $\left.=0.85\right)$. Only one subject had no risk alleles and was therefore included in the 1-allele group.

Although weight gain was not correlated with risperidone dose ( $r=-0.09, P=0.24)$, we repeated the analyses using dose as a covariate to rule out any confounding effects; risperidone dose did not contribute to the effects of genotype (rs806378, $P=0.68 ; \quad r s 1049353, P=0.68 ; \quad r s 7799039$, $P=0.86)$. In addition, as trough plasma levels were obtained for the RUPP samples, the markers with significant associations were analyzed in the RUPP subsample using plasma level as a covariate. Surprisingly, despite the much smaller sample size $(n=34)$, rs1049353 $(P<0.005)$ and rs7799039 $(P<0.05)$ both retained nominal significance, however, rs806378 did not $(P=0.26)$; plasma level did not account for these effects (rs806378, $P=0.41$; rs1049353, $P=0.49$; rs7799039, $P=0.54$ ). Finally, although there were no significant difference in weight gained (Z-score) in the Caucasian versus non-Caucasian groups, analyses of the three significant markers included ethnicity as a covariate and were reanalyzed in the Caucasian subsample $(n=119)$. No main effect of ethnicity was observed (rs806378 $P=0.60$, rs1049353 $P=0.66$, rs7799039 $P=0.86), P$-values were similar whether or not ethnicity was included in the model, and all three SNPs retained significance in the smaller Caucasian subsample (rs806378, $P=1.8 \times 10^{-3}$; rs1049353, $P=8.63$ $\times 10^{-6} ;$ rs $7799039, P=4.5 \times 10^{-5}$ ).

In order to test for overlapping or interactive effects between these three variants, we calculated a risk score for each subject by assigning one point for the presence of a risk allele at each identified locus (Figure 2). This model strongly predicted weight gain in both the overall sample $(P=1.29$ $\left.\times 10^{-9}\right)$ and the Caucasian subset $\left(P=2.13 \times 10^{-11}\right)$. The addition of each risk allele conferred an independent risk; subjects with 0 or 1 risk alleles (combined as only one subject had no risk alleles) gained the least weight and those with three alleles gained the most (Cohen's D effect size 0.46 for $0 / 1$ versus 2 and 0.85 for $0 / 1$ versus 3 ). In all, $64 \%$ of the variance in weight gained was explained by the combined risk by time model.

\section{Discussion}

Our results form strong support for individual genetic variation in the LEP and CNR1 genes as moderators of AIWG. SGAs may impact appetite, weight gain and energy expenditure through direct or indirect interactions with these key regulators of energy balance. Although the exact mechanisms of these effects are unknown, our data suggest that genetic regulation of energy balance components may impact energy homeostasis in the face of antipsychotic exposure. The prominent role of promoter, rather than coding, variants in both genes implies that regulation of gene expression may be an important mechanism. Future studies should examine gene expression profiles during SGA exposure, with particular interest in the expression of the significantly associated loci identified in this report.

In this sample of children and adolescents with ASD, individuals with at least one copy of the T-allele of CNR1 SNP rs806378 showed greater weight gain during low-dose risperidone exposure, evident even after only the first 8 weeks of treatment. As our data are in agreement with a prior study in adults with schizophrenia receiving olanzapine, ${ }^{44}$ this variant may confer broad risk for AIWG. This SNP localizes immediately adjacent to the coding region in either the putative promoter, the $5^{\prime}$ untranslated region or the large first intron in alternative transcripts of $C N R 1$, and mechanistically it has been suggested to impact a binding site for a transcription factor involved in regulating hypothalamic feeding drives. ${ }^{44}$ Despite the inclusion of the upstream alternative promoter and untranslated exon in several prior studies, all association signals have localized to the $3^{\prime}$ LD block tagged in the present analyses. Allelic heterogeneity and possible differential ethnic risk affecting this locus may help to explain disparate findings in published studies. Another nearby SNP (rs806377) and a $3^{\prime}$ untranslated region polymorphism (rs806368) previously reported to associate with obesity phenotypes were not associated with AIWG in our sample. ${ }^{37,60}$ Association with fat mass and BMI of the G-allele of synonymous SNP rs1049353 was previously reported and replicated, ${ }^{61,62}$ although not all studies are in agreement. ${ }^{60,63,64}$ In all positive reports, including the present study, the G-allele is associated with risk for weight gain or related phenotypes. Synonymous SNPs may be directly relevant by altering translational efficiency or by impacting mRNA processing, stability or localization, or may reflect indirect association through LD with a nearby functional variant. Indeed, HaploReg analysis indicates that this SNP is in near perfect LD with a $3^{\prime}$ untranslated region variant mapping to a region of active transcription factor binding (rs4707436). The two associated CNR1 variants reflect independent associations, as LD between these two SNPs is negligible $\left(r^{2}=0.01\right)$. Despite previous support, ${ }^{45}$ the single nonsynonymous variant in $F A A H$ was non-significant in our data set. 
We report a substantial contribution of the LEP rs7799039 (G-2548A) promoter SNP with individual differences in weight gain, as have multiple prior studies, including one in children. ${ }^{40}$ In our sample, the G-allele conferred a dominant effect on risk for weight gain. Data from several groups support this directionality of effect for AIWG ${ }^{65-69}$ and related phenotypes. ${ }^{70,71} \mathrm{~A}$ few studies have found no evidence for association at this locus. ${ }^{72,73}$ Three studies have found association of the A-allele with AIWG in Asian populations, ${ }^{74-76}$ as well as a single smaller mixed-ethnicity pediatric study, which also showed LEP elevation for carriers of the A-allele. ${ }^{40}$ Taken together, our data stand in agreement with the majority of reports; those studies with contrary patterns of association with AIWG and the A-allele appear to differ by virtue of effects of ethnicity. Of the two negative reports, one sample was significantly smaller than ours, and both involved a mixture of various antipsychotics, including other concomitant medications. It is conceivable that some associations with AIWG will emerge to be medication specific. Interestingly, in the only prior pediatric report, A-carriers had greater weight gain and higher LEP concentrations at lower BMls overall, however, the magnitude of the increase in LEP with BMI was greater for GG homozygotes, arguing that this SNP may indeed produce differential LEP expression. ${ }^{40}$ In concordance with this finding, higher transcription factor binding to the $L E P$ promoter, LEP expression and LEP secretion has been demonstrated in non-obese AA homozygotes compared with G-carriers. ${ }^{77}$ Interestingly, in silico investigation also suggests that this SNP may be functional, as it tags an LD block annotated by HaploReg as containing multiple enhancer elements.

The marginal association of SNPs in the obesity-related gene, MC4R deserves mention. Our MC4R results stand in contrast to recent strong associations with AIWG. However, we note three possibly relevant study differences. Our sample tested only associations with risperidone monotherapy, whereas the positive $M C 4 R$ reports examined associations with multiple, mostly other SGAs, not risperidone. Our sample is considerably younger (mean age 9 years) than most; it is conceivable that age and developmental stage interacts with gene-weight gain relations. Our sample is also unique in that is only includes subjects with ASD, rather than the majority of reports of adolescents and adults with psychotic and other disorders. Each of these differences may be relevant to genetic associations with AIWG. Clinically, it is of note that the inverse correlation of AIWG with clinical improvement on the primary outcome measure concurs with our RUPP report that weight gained negatively mediated risperidone benefit, ${ }^{78}$ which could have implications for drug development. However, the mechanism of antipsychotic action in autism-associated aggression may be distinct from activity in psychotic disorders; indeed, the relationship between efficacy and weight gain appears to be positively correlated in studies of psychosis. ${ }^{79,80}$

Our investigation likely benefited from several features: the largely treatment-naive sample of youth with a single disorder (ASD), observations of weight with risperidone monotherapy only, weekly monitoring and data collection allowing a powerful repeated measures statistical model and a more rigorous query of candidate genes. As repeated measures of weight gain across eight visits were tightly correlated $(r=0.95)$, this study was powered to detect effect sizes ranging from 0.15 to 0.32 based on the minor allele frequency of the variant. The clinical impact of the variants reported here appear significant given the large effect size. It is conceivable that these associations could become even more robust if measured over longer periods of drug exposure. To our knowledge, this study represents the only examination of the endocannabinoid system in children, who may suffer greater morbidity both in terms of magnitude of weight gained and health impact across the lifespan. Importantly, the support for involvement of CNR1 signaling suggests that the use of known drug modulators of this system, such as those similar to rimonabant, could limit the extent of AIWG, especially in those individuals at higher genetic risk.

Although our study is limited by a relatively modest number of subjects, results did withstand correction for multiple testing. Although a functional variant in the FAAH enzyme and highly associated FTO markers were chosen for inclusion based on prior data, these genes were not comprehensively screened. A larger sample would provide the statistical power to permit the inclusion of additional markers, either within these genes or other components of the energy balance system, or allow a full selection-unbiased genome-wide association study. Similarly, other metabolic response 'phenotypes', such as hip and waist circumference, lipid profile and measures of glucose metabolism, could also be examined, ${ }^{6}$ although the current sample size lacks desired power for broader exploration.

Taken together, our data and prior evidence support a moderating role of genetic variation in the LEP and endocannabinoid system on AIWG. Additional efforts to replicate and extend these findings to larger samples, to understand the biological basis for these associations and to examine possible clinical implications by a priori risk prediction and genotype-driven treatment matching are suggested as future directions. Polygenic inheritance, small effect sizes and genetic and phenotypic heterogeneity have limited the identification of genetic moderators of complex phenotypes. However, understanding the risk for tractable and quantitative adverse drug effects informed by underlying biology may pose a less complex genetic question. The pharmacogenetics of AIWG may offer a window into the intricate physiology of energy balance and guide the personalization of treatment to improve clinical outcomes.

\section{Conflict of interest}

Dr Aman has received consulting fees from Bristol-Myers Squibb, BioMarin, Roche and Supernus. Dr Aman also reports research support from Bristol-Myers Squibb and Johnson and Johnson. Dr Arnold has received research funding from Curemark, Shire and Lilly, and has consulted on advisory boards for AstraZeneca, Biomarin, Novartis, Noven, Seaside Therapeutics and Shire. Dr Handen reports research support from Eli Lilly, Curemark and Bristol Myers Squibb. Dr McCracken reports receiving consulting fees from BioMarin, Novartis and PharmaNet; he also reports research support from Bristol-Myers Squibb, Roche and Seaside Therapeutics. Dr McDougle reports having received consultant fees from BristolMyers Squibb, Hoffman-LaRoche and Forest Research Institute; he has also received research support and is on the speakers' bureau of Bristol-Myers Squibb. Dr Scahill reports receiving consultant fees 
from Brackett, Pfizer, Hoffman, BioMarin; he has also received research support from Pfizer, Shire and Hoffman. Dr Stigler reports receiving research support from Bristol-Myers Squibb, Eli Lilly, Jansen, Novartis, Forest Research Institute and Seaside Therapeutics. The remaining authors declare no conflict of interest.

Acknowledgements. This work was partially supported by the following sources: NIMH grants T32MH073517 (ELN), K23 MH094613 (ELN), K24 MH010805 (JTM) and N01MH70010 (JTM), N01MH80011 and U10MH66768 (MGA), N01MH70001 and U10MH66766 (CJM), N01MH70009 and U10MH66764 (LLS) and a grant from the Korczak Foundation (LLS). Study medications were donated by Janssen Pharmaceutica.

1. Allison DB, Mentore JL, Heo M, Chandler LP, Cappelleri JC, Infante MC et al. Antipsychotic-induced weight gain: a comprehensive research synthesis. Am J Psychiatry 1999: 156: 1686-1696.

2. Theisen FM, Gebhardt S, Haberhausen M, Heinzel-Gutenbrunner M, Wehmeier PM, Krieg $\mathrm{JC}$ et al. Clozapine-induced weight gain: a study in monozygotic twins and same-sex sib pairs. Psychiatr Genet 2005; 15: 285-289.

3. Nasrallah HA. Atypical antipsychotic-induced metabolic side effects: insights from receptorbinding profiles. Mol Psychiatry 2008; 13: 27-35.

4. De Luca V, Mueller DJ, de Bartolomeis A, Kennedy JL. Association of the HTR2C gene and antipsychotic induced weight gain: a meta-analysis. Int $J$ Neuropsychopharmacol 2007; 10: 697-704

5. Lett TA, Wallace TJ, Chowdhury NI, Tiwari AK, Kennedy JL, Muller DJ. Pharmacogenetics of antipsychotic-induced weight gain: review and clinical implications. Mol Psychiatry 2011; 17: $242-266$

6. Adkins DE, Aberg K, McClay JL, Bukszar J, Zhao Z, Jia P et al. Genomewide pharmacogenomic study of metabolic side effects to antipsychotic drugs. Mol Psychiatry 2011; 16: 321-332.

7. Albarado DC, McClaine J, Stephens JM, Mynatt RL, Ye J, Bannon AW et al. Impaired coordination of nutrient intake and substrate oxidation in melanocortin-4 receptor knockout mice. Endocrinology 2004; 145: 243-252.

8. Song CK, Jackson RM, Harris RB, Richard D, Bartness TJ. Melanocortin-4 receptor mRNA is expressed in sympathetic nervous system outflow neurons to white adipose tissue. Am J Physiol Regul Integr Comp Physiol 2005; 289: R1467-R1476.

9. Farooqi IS, O'Rahilly S. Genetic factors in human obesity. Obes Rev 2007; 8(Suppl 1): $37-40$.

10. Fredriksson R, Hagglund M, Olszewski PK, Stephansson O, Jacobsson JA, Olszewska AM et al. The obesity gene, FTO, is of ancient origin, up-regulated during food deprivation and expressed in neurons of feeding-related nuclei of the brain. Endocrinology 2008; 149 2062-2071.

11. Frayling TM, Timpson NJ, Weedon MN, Zeggini E, Freathy RM, Lindgren CM et al. A common variant in the FTO gene is associated with body mass index and predisposes to childhood and adult obesity. Science 2007; 316: 889-894.

12. Peng S, Zhu Y, Xu F, Ren X, Li X, Lai M. FTO gene polymorphisms and obesity risk: a meta-analysis. BMC Med 2011: 9: 71 .

13. Tung YC, Ayuso E, Shan X, Bosch F, O'Rahilly S, Coll AP et al. Hypothalamic-specific manipulation of Fto, the ortholog of the human obesity gene FTO, affects food intake in rats. PLoS One 2010; 5: e8771.

14. Tung YC, Yeo GS. From GWAS to biology: lessons from FTO. Ann N Y Acad Sci 2011; 1220: $162-171$.

15. Cowley MA, Smart JL, Rubinstein M, Cerdan MG, Diano S, Horvath TL et al. Leptin activates anorexigenic POMC neurons through a neural network in the arcuate nucleus. Nature 2001; 411: 480-484

16. Opland DM, Leinninger GM, Myers MG Jr.. Modulation of the mesolimbic dopamine system by leptin. Brain Res 2010; 1350: 65-70.

17. Davis JF, Choi DL, Schurdak JD, Fitzgerald MF, Clegg DJ, Lipton JW et al. Leptin regulates energy balance and motivation through action at distinct neural circuits. Biol Psychiatry 2011; 69: 668-674.

18. Siegrist-Kaiser CA, Pauli V, Juge-Aubry CE, Boss O, Pernin A, Chin WW et al. Direct effects of leptin on brown and white adipose tissue. J Clin Invest 1997; 100: 2858-2864.

19. Kamohara S, Burcelin R, Halaas JL, Friedman JM, Charron MJ Acute stimulation of glucose metabolism in mice by leptin treatment. Nature 1997; 389: 374-377.

20. Zhang Y, Proenca R, Maffei M, Barone M, Leopold L, Friedman JM. Positional cloning of the mouse obese gene and its human homologue. Nature 1994; 372: 425-432.

21. Matheny M, Zhang Y, Shapiro A, Tumer N, Scarpace PJ. Central overexpression of leptin antagonist reduces wheel running and underscores importance of endogenous leptin receptor activity in energy homeostasis. Am J Physiol Regul Integr Comp Physiol 2009; 297: R1254-R1261.

22. Paz-Filho G, Wong ML, Licinio J. Ten years of leptin replacement therapy. Obes Rev 2011 12: e315-e323.
23. Yu Z, Han S, Cao X, Zhu C, Wang X, Guo X. Genetic polymorphisms in adipokine genes and the risk of obesity: a systematic review and meta-analysis. Obesity (Silver Spring) 2011; 20: 396-406.

24. Pagotto U, Marsicano G, Cota D, Lutz B, Pasquali R. The emerging role of the endocannabinoid system in endocrine regulation and energy balance. Endocr Rev 2006; 27: $73-100$

25. Verty AN, McGregor IS, Mallet PE. The dopamine receptor antagonist SCH 23390 attenuates feeding induced by Delta9-tetrahydrocannabinol. Brain Res 2004; 1020: 188-195.

26. Duarte $\mathrm{C}$, Alonso R, Bichet N, Cohen C, Soubrie P, Thiebot MH. Blockade by the cannabinoid CB1 receptor antagonist, rimonabant (SR141716), of the potentiation by quinelorane of food-primed reinstatement of food-seeking behavior. Neuropsychopharmacology 2004; 29: 911-920.

27. Hilairet S, Bouaboula M, Carriere D, Le Fur G, Casellas P. Hypersensitization of the Orexin 1 receptor by the CB1 receptor: evidence for cross-talk blocked by the specific CB1 antagonist, SR141716. J Biol Chem 2003; 278: 23731-23737.

28. Verty AN, McFarlane JR, McGregor IS, Mallet PE. Evidence for an interaction between CB1 cannabinoid and melanocortin MCR-4 receptors in regulating food intake. Endocrinology 2004; 145: 3224-3231.

29. Tucci SA, Rogers EK, Korbonits M, Kirkham TC. The cannabinoid CB1 receptor antagonist SR141716 blocks the orexigenic effects of intrahypothalamic ghrelin. Br J Pharmacol 2004; 143: $520-523$.

30. Di Marzo V, Goparaju SK, Wang L, Liu J, Batkai S, Jarai Z et al. Leptin-regulated endocannabinoids are involved in maintaining food intake. Nature 2001; 410: 822-825.

31. Di Marzo V, Matias I. Endocannabinoid control of food intake and energy balance. Nat Neurosci 2005; 8: 585-589.

32. Pagano C, Rossato M, Vettor R. Endocannabinoids, adipose tissue and lipid metabolism. J Neuroendocrinol 2008; 20(Suppl 1): 124-129.

33. Ward SJ, Dykstra LA. The role of CB1 receptors in sweet versus fat reinforcement: effect of CB1 receptor deletion, $\mathrm{CB} 1$ receptor antagonism (SR141716A) and CB1 receptor agonism (CP-55940). Behav Pharmacol 2005; 16: 381-388.

34. Di Marzo V. Targeting the endocannabinoid system: to enhance or reduce? Nat Rev Drug Discov 2008; 7: 438-455.

35. Ravinet Trillou C, Delgorge C, Menet C, Arnone M, Soubrie P. CB1 cannabinoid receptor knockout in mice leads to leanness, resistance to diet-induced obesity and enhanced leptin sensitivity. Int J Obes Relat Metab Disord 2004; 28: 640-648.

36. Lieb W, Manning AK, Florez JC, Dupuis J, Cupples LA, McAteer JB et al. Variants in the CNR1 and the FAAH genes and adiposity traits in the community. Obesity (Silver Spring) 2009; 17: 755-760.

37. Schleinitz D, Carmienke S, Bottcher Y, Tonjes A, Berndt J, Kloting N et al. Role of genetic variation in the cannabinoid type 1 receptor gene (CNR1) in the pathophysiology of human obesity. Pharmacogenomics 2010; 11: 693-702.

38. Pi-Sunyer FX, Aronne LJ, Heshmati HM, Devin J, Rosenstock J. Effect of rimonabant, a cannabinoid-1 receptor blocker, on weight and cardiometabolic risk factors in overweight or obese patients: RIO-North America: a randomized controlled trial. JAMA 2006; 295: 761-775

39. Sentissi O, Epelbaum J, Olie JP, Poirier MF. Leptin and ghrelin levels in patients with schizophrenia during different antipsychotics treatment: a review. Schizophr Bull 2008; 34 1189-1199.

40. Calarge CA, Ellingrod VL, Zimmerman B, Acion L, Sivitz WI, Schlechte JA. Leptin gene $2548 \mathrm{G} / \mathrm{A}$ variants predict risperidone-associated weight gain in children and adolescents. Psychiatr Genet 2009; 19: 320-327.

41. Chowdhury NI, Tiwari AK, Souza RP, Zai CC, Shaikh SA, Chen S et al. Genetic association study between antipsychotic-induced weight gain and the melanocortin-4 receptor gene. Pharmacogenomics J 2013; 13: 272-279.

42. Malhotra AK, Correll CU, Chowdhury NI, Muller DJ, Gregersen PK, Lee AT et al. Association between common variants near the melanocortin 4 receptor gene and severe antipsychotic drug-induced weight gain. Arch Gen Psychiatry 2012; 69: 904-912.

43. Cheng MC, Liao DL, Hsiung CA, Chen CY, Liao YC, Chen $\mathrm{CH}$. Chronic treatment with aripiprazole induces differential gene expression in the rat frontal cortex. Int J Neuropsychopharmacol 2008; 11: 207-216.

44. Tiwari AK, Zai CC, Likhodi O, Lisker A, Singh D, Souza RP et al. A common polymorphism in the cannabinoid receptor 1 (CNR1) gene is associated with antipsychotic-induced weight gain in Schizophrenia. Neuropsychopharmacology 2010; 35: 1315-1324.

45. Monteleone P, Milano W, Petrella C, Canestrelli B, Maj M. Endocannabinoid Pro129Thr FAAH functional polymorphism but not 1359G/A CNR1 polymorphism is associated with antipsychotic-induced weight gain. J Clin Psychopharmacol 2010; 30: 441-445.

46. Ratzoni G, Gothelf D, Brand-Gothelf A, Reidman J, Kikinzon L, Gal G et al. Weight gain associated with olanzapine and risperidone in adolescent patients: a comparative prospective study. J Am Acad Child Adolesc Psychiatry 2002; 41: 337-343.

47. Kelly DL, Conley RR, Love RC, Horn DS, Ushchak CM. Weight gain in adolescents treated with risperidone and conventional antipsychotics over six months. J Child Adolesc Psychopharmacol 1998; 8: 151-159.

48. Martin A, Landau J, Leebens P, Ulizio K, Cicchetti D, Scahill L et al. Risperidoneassociated weight gain in children and adolescents: a retrospective chart review. J Child Adolesc Psychopharmacol 2000; 10: 259-268. 
49. Woods SW, Martin A, Spector SG, McGlashan TH. Effects of development on olanzapineassociated adverse events. J Am Acad Child Adolesc Psychiatry 2002; 41: 1439-1446.

50. Martin A, Scahill L, Anderson GM, Aman M, Arnold LE, McCracken J et al. Weight and leptin changes among risperidone-treated youths with autism: 6-month prospective data. Am J Psychiatry 2004; 161: 1125-1127.

51. McCracken JT, McGough J, Shah B, Cronin P, Hong D, Aman MG et al. Risperidone in children with autism and serious behavioral problems. N Engl J Med 2002; 347: 314-321.

52. Aman MG, McDougle CJ, Scahill L, Handen B, Arnold LE, Johnson C et al. Medication and parent training in children with pervasive developmental disorders and serious behavior problems: results from a randomized clinical trial. J Am Acad Child Adolesc Psychiatry 2009; 48: 1143-1154.

53. Aravagiri M, Marder SR, Wirshing D, Wirshing WC. Plasma concentrations of risperidone and its 9-hydroxy metabolite and their relationship to dose in schizophrenic patients: simultaneous determination by a high performance liquid chromatography with electrochemical detection. Pharmacopsychiatry 1998; 31: 102-109.

54. Growth Chart Training: Resources: SAS Program. http://www.cdc.gov/nccdphp/dnpao/ growthcharts/resources/sas.htm 2011 Accessed Date 2011

55. deBakker PI, Yelensky R, Pe'er I, Gabriel SB, Daly MJ, Altshuler D. Efficiency and power in genetic association studies. Nat Genet 2005; 37: 1217-1223.

56. Thorisson GA, Smith AV, Krishnan L, Stein LD. The International HapMap Project Web site. Genome Res 2005; 15: 1592-1593.

57. Kent WJ, Sugnet CW, Furey TS, Roskin KM, Pringle TH, Zahler AM et al. The human genome browser at UCSC. Genome Res 2002; 12: 996-1006.

58. Rosenbloom KR, Dreszer TR, Long JC, Malladi VS, Sloan CA, Raney BJ et al. ENCODE whole-genome data in the UCSC Genome Browser: update 2012. Nucleic Acids Res 2012; 40, Database issue D912-D917.

59. Ward LD, Kellis M. HaploReg: a resource for exploring chromatin states, conservation, and regulatory motif alterations within sets of genetically linked variants. Nucleic Acids Res 2012; 40, Database issue D930-D934.

60. Jaeger JP, Mattevi VS, Callegari-Jacques SM, Hutz MH. Cannabinoid type-1 receptor gene polymorphisms are associated with central obesity in a Southern Brazilian population. Dis Markers 2008; 25: 67-74.

61. Luis DA, Gonzalez Sagrado M, Aller R, Izaola O, Conde R, Perez Castrillon JL et al. [G1359A polymorphism of the cannabinoid receptor gene (CNR1) on anthropometric parameters and cardiovascular risk factors in patients with morbid obesity]. Nutr Hosp 2009; 24: 688-692.

62. Gazzerro P, Caruso MG, Notarnicola M, Misciagna G, Guerra V, Laezza C et al. Association between cannabinoid type-1 receptor polymorphism and body mass index in a southern Italian population. Int J Obes (Lond) 2007; 31: 908-912.

63. de Luis DA, Gonzalez Sagrado M, Aller R, Izaola O, Conde R, Romero E. G1359A polymorphism of the cannabinoid receptor gene (CNR1) and insulin resistance in patients with diabetes mellitus type 2. Nutr Hosp 2010; 25: 34-38.

64. Park YM, Choi JE, Kang SG, Koo SH, Kim L, Geum D et al. Cannabinoid type 1 receptor gene polymorphisms are not associated with olanzapine-induced weight gain. Hum Psychopharmacol 2011; 26: 332-337.

65. Templeman LA, Reynolds GP, Arranz B, San L. Polymorphisms of the 5-HT2C receptor and leptin genes are associated with antipsychotic drug-induced weight gain in Caucasian subjects with a first-episode psychosis. Pharmacogenet Genomics 2005; 15: 195-200.

66. Ellingrod VL, Bishop JR, Moline J, Lin YC, Miller DD. Leptin and leptin receptor gene polymorphisms and increases in body mass index (BMI) from olanzapine treatment in persons with schizophrenia. Psychopharmacol Bull 2007; 40: 57-62.

67. Kang SG, Lee HJ, Park YM, Choi JE, Han C, Kim YK et al. Possible association between the $-2548 \mathrm{~A} / \mathrm{G}$ polymorphism of the leptin gene and olanzapine-induced weight gain. Prog Neuropsychopharmacol Biol Psychiatry 2008; 32: 160-163.

68. Yevtushenko OO, Cooper SJ, O'Neill R, Doherty JK, Woodside JV, Reynolds GP. Influence of $5-\mathrm{HT} 2 \mathrm{C}$ receptor and leptin gene polymorphisms, smoking and drug treatment on metabolic disturbances in patients with schizophrenia. Br J Psychiatry 2008; 192: 424-428.

69. Brandl EJ, Frydrychowicz C, Tiwari AK, Lett TA, Kitzrow W, Buttner S et al. Association study of polymorphisms in leptin and leptin receptor genes with antipsychotic-induced body weight gain. Prog Neuropsychopharmacol Biol Psychiatry 2012; 38: 134-141.

70. Fernandez E, Carrizo E, Fernandez V, Connell L, Sandia I, Prieto D et al. Polymorphisms of the LEP- and LEPR genes, metabolic profile after prolonged clozapine administration and response to the antidiabetic metformin. Schizophr Res 2010; 121: 213-217.

71. Kuo PH, Kao CF, Chen PY, Chen CH, Tsai YS, Lu ML et al. Polymorphisms of INSIG2, MC4R, and LEP are associated with obesity- and metabolic-related traits in schizophrenic patients. J Clin Psychopharmacol 2011; 31: 705-711.
72. Opgen-Rhein C, Brandl EJ, Muller DJ, Neuhaus AH, Tiwari AK, Sander T et al. Association of HTR2C, but not LEP or INSIG2, genes with antipsychotic-induced weight gain in a German sample. Pharmacogenomics 2010; 11: 773-780.

73. Perez-Iglesias R, Mata I, Amado JA, Berja A, Garcia-Unzueta MT, Martinez Garcia $O$ et al. Effect of FTO, SH2B1, LEP, and LEPR polymorphisms on weight gain associated with antipsychotic treatment. J Clin Psychopharmacol 2010; 30: 661-666.

74. Zhang ZJ, Yao ZJ, Mou XD, Chen JF, Zhu RX, Liu W et al. [Association of -2548G/A functional polymorphism in the promoter region of leptin gene with antipsychotic agentinduced weight gain]. Zhonghua Yi Xue Za Zhi 2003; 83: 2119-2123.

75. Zhang XY, Tan YL, Zhou DF, Haile CN, Cao LY, Xu Q et al. Association of clozapineinduced weight gain with a polymorphism in the leptin promoter region in patients with chronic schizophrenia in a Chinese population. J Clin Psychopharmacol 2007; 27: 246-251.

76. Wu R, Zhao J, Shao P, Ou J, Chang M. Genetic predictors of antipsychotic-induced weight gain: a case-matched multi-gene study. Zhong Nan Da Xue Xue Bao Yi Xue Ban 2011; 36: 720-723.

77. Hoffstedt J, Eriksson P, Mottagui-Tabar S, Arner P. A polymorphism in the leptin promoter region $(-2548 \mathrm{G} / \mathrm{A})$ influences gene expression and adipose tissue secretion of leptin. Horm Metab Res 2002; 34: 355-359.

78. Arnold LE, Farmer C, Kraemer HC, Davies M, Witwer A, Chuang S et al. Moderators, mediators, and other predictors of risperidone response in children with autistic disorder and irritability. J Child Adolesc Psychopharmacol 2010; 20: 83-93.

79. Ascher-Svanum H, Stensland MD, Kinon BJ, Tollefson GD. Weight gain as a prognostic indicator of therapeutic improvement during acute treatment of schizophrenia with placebo or active antipsychotic. J Psychopharmacol 2005; 19(6 Suppl): 110-117.

80. Hermes E, Nasrallah H, Davis V, Meyer J, McEvoy J, Goff D et al. The association between weight change and symptom reduction in the CATIE schizophrenia trial. Schizophr Res 2011; 128: 166-170.

81. Xi B, Wang C, Wang R, Huang Y. FTO gene polymorphisms are associated with obesity and type 2 diabetes in East Asian populations: an update. Obesity (Silver Spring) 2011; 19: 236-237; author reply 238.

82. Li S, Zhao JH, Luan J, Luben RN, Rodwell SA, Khaw KT et al. Cumulative effects and predictive value of common obesity-susceptibility variants identified by genome-wide association studies. Am J Clin Nutr 2010; 91: 184-190.

83. Scott RA, Bailey ME, Moran CN, Wilson RH, Fuku N, Tanaka M et al. FTO genotype and adiposity in children: physical activity levels influence the effect of the risk genotype in adolescent males. Eur J Hum Genet 2010; 18: 1339-1343.

84. Beckers S, Zegers D, de Freitas F, Mertens IL, Van Gaal LF, Van Hul W. Association study of MC4R with complex obesity and replication of the rs17782313 association signal. Mol Genet Metab 2011; 103: 71-75.

85. Malhotra AK, Correll CU, Chowdhury NI, Müller DJ, Gregersen PK, Lee AT et al. Common variants near the melanocortin 4 receptor gene are associated with severe antipsychotic drug-induced weight gain. Arch Gen Psychiatry 2012; 69: 904-912.

86. Gregoor JG, van der Weide J, Loovers HM, van Megen HJ, Egberts TC, Heerdink ER. Association between LEP and LEPR gene polymorphisms and dyslipidemia in patients using atypical antipsychotic medication. Psychiatr Genet 2010; 20: 311-316.

87. Gregoor JG, van der Weide J, Loovers HM, van Megen HJ, Egberts TC, Heerdink ER. Polymorphisms of the LEP, LEPR and HTR2C gene: obesity and BMI change in patients using antipsychotic medication in a naturalistic setting. Pharmacogenomics 2011; 12: 919-923.

88. Labayen I, Ruiz JR, Moreno LA, Ortega FB, Beghin L, DeHenauw S et al. The effect of ponderal index at birth on the relationships between common LEP and LEPR polymorphisms and adiposity in adolescents. Obesity (Silver Spring) 2011; 19: 2038-2045.

89. Erez G, Tirosh A, Rudich A, Meiner V, Schwarzfuchs D, Sharon N et al. Phenotypic and genetic variation in leptin as determinants of weight regain. Int $J$ Obes (Lond) 2011; 35: 785-792.

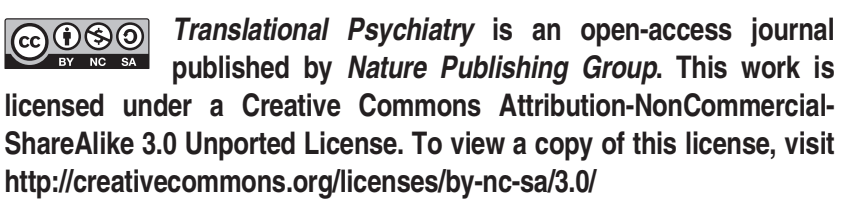

Supplementary Information accompanies the paper on the Translational Psychiatry website (http://www.nature.com/tp) 